\title{
Work-related stress and performance among primary school teachers
}

\author{
Sandra Ingried Asaloei ${ }^{1}$, Agustinus Kia Wolomasi ${ }^{2}$, Basilius Redan Werang ${ }^{3}$ \\ ${ }^{1}$ Faculty of Administrative Sciences, Universitas Sam Ratulangi, Indonesia \\ ${ }^{2}$ Catholic College of Santo Yakobus, Indonesia \\ ${ }^{3}$ Faculty of Teacher Training and Education, Universitas Musamus, Indonesia
}

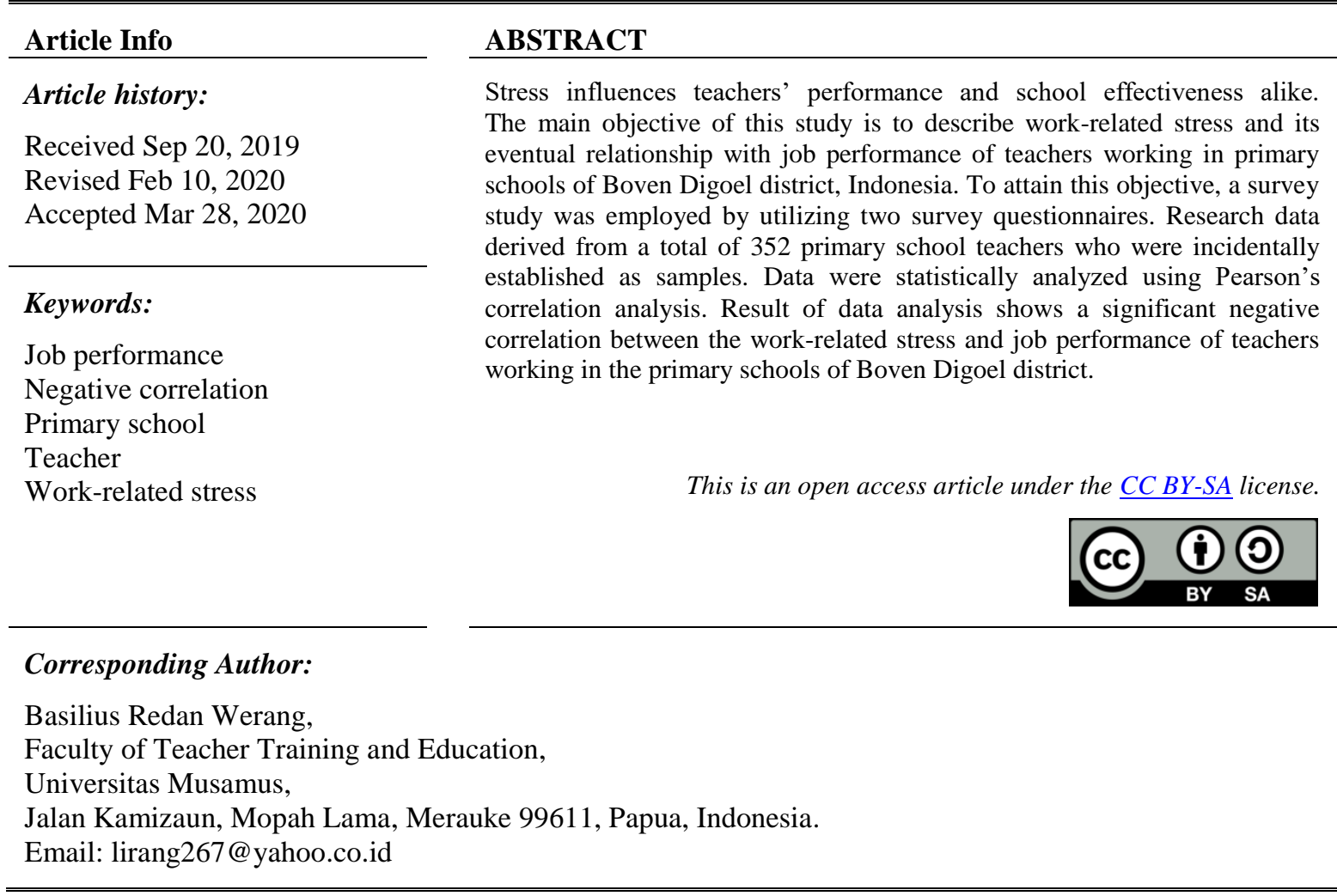

\section{INTRODUCTION}

Teaching has conventionnaly been considered as a low-stress profession [1], but the situation has been somersaulted during these last three decades [2]. Many studies (e.g. [3-11]) have revealed that teaching is the most stressful profession/job comparing to other professions/jobs. Poor working conditions in the primary schools of Papua in general and of Boven Digoel district in particular [12] requires highly physical, intellectual, and emotional health of teachers involved, still, there are diverse emotional and knowledgeable indicators of work-related stress that may disturb teachers personally and, in turn, effect negatively on their capacity to teach the youth [13]. In line with this argument, a high-level of teacher absenteeism and primary school students' incapability in reading, writing, and arithmetic (3 Rs) as reported by $[14,15]$ could then be attributed to the teachers' stress.

Wong and Cheuk [16] referred to stress as a general term applied to the pressure people felt in life. Olson et al. [17] described stress as a condition of pressure emanated from an apparent call for a modification of adaptive conduct. Dunham [18] described stress as a procedure of conduct, emotional, and physical responses emanated from persistent stresses that are totally bigger than the accessibility of adapting systems. Whereas Hassan (as cited in [19]) viewed stress as an arousal reaction, positive or negative, to some work personal related stimulus. Stress is positive if it motivates a person to act in a given situation, while it is negative if it becomes excessive and causes a person for reducing his/her performance or not performing at all. 
The term stress here refers to teacher work-related stress. An early analysis on teacher stress derived from Kyriacou and Sutcliffe [20] who viewed teacher stress as a reaction pattern facilitated by an evaluation of risk to the pride or welfare of teachers or by managing devices activated to decrease the apparent pressure. Kyriacou [10] described teacher work-related stress in terms of unhappy negative feelings, such as pressure, hindrance, nervousness, and depression that teacher finds in some aspects of his/her work. National Institute for Occupational Safety and Health [21] described teacher work-related stress as the damaging physical and mental reactions that happen when teachers' abilities and desires are not in line with the job's requirements. In the similar way, World Health Organization [22] defined teacher work-related stress as a form of response that occurs when the work demands offered do not match teachers' knowledge, skills or abilities.

Kyriacou [10] posited that sources of stress facing an individual teacher are unique, rely upon the specific complex interaction between teacher's character, beliefs, abilities, and environments. Numerous reports (e.g. [23-32]) exposed that teachers are uncovered to different source of stress, such as: educating uninterested learners, poor prepared learners, poor learners conducts, supporting discipline in the classroom, a demanding workload (curriculum demands), role overload, great prospects, lack of compensation and appreciation, being unprotected to common changes, time pressures, being accessed by others, experiencing problematic relations with coworkers and superiors, management styles, and poor working circumstances.

Teachers' work-related stress has been known as linked to their job performance. Teachers' job performance can be simply defined as the entire predictable value that a teacher has to carry out over a standard period of time. Borman and Motowidlo [33] posited that the total of eventual constructs of the job performance can be grouped into two broad types: (a) task performance: refers to activities related to the execution and maintenance of core technical process in a particular organization and (b) contextual performance: refers to activities that contribute to organizational effectiveness in ways that shape the organizational, social, and psychological environment in which the technical core functions [34-37]. Borman and Motowidlo [33] further classified task performance into two types: (a) activities that convert materials into good and services, and (b) activities that service and maintain the technical core by replenishing its supply of raw materials, distributing its finished products; or delivering essential planning, coordination, direction; or staff roles that support it to effectively and efficiently function. Whereas, Sonentag et al. [38] enumerated five categories of contextual performance as follows: (a) undertaking events beyond a person's formal job requirements; (b) tenacity of eagerness when needed to complete essential task requirements; (c) assisting others; (d) obeying instructions and prescribed procedures even when it is inconvenient; and (e) defending the organization's objectives openly.

The accessible literature contains different current studies on how work-related stress predicted job performance, both in the context of organizations in general and in the context of school in particular. Yunarti et al. [39] examined the work-related stress of teachers working in primary schools of Southern Papua and how it predicts teachers' job performance. Employing incidental sampling, a total of 1062 primary school teachers were selected as samples. Derivative data were statistically examined. Using simple linear regression as the tool for data analyzing, the study concluded that job performance of teachers working in the primary schools of Southern Papua was significant negatively predicted by teachers' work-related stress.

Vijayan [40] examined work-related stress and performance of employees working in Aavin Company, Coimbatore. Employing simple random sampling, a total of 100 employees were selected as samples. The study found that male workers are more worried about work safety and shift work. At the end of the study, researcher concluded that the selected construct of work stress is confidently related each other and effect positively on performance of employees working in the Aavin Company, Coimbatore.

Amoako et al. [41] examined occupational stress and how it affect job performance at Aspect A Company Limited. Employing a convenience sampling technique, the researchers established 109 employees working at the Aspet A Company Limited as samples. The study concluded that work-related stress enhances employees' performance in a positive and significant manner. At the end of the study the researchers argued that as the work-related stress of employees increase, the performance of employees tend to increase and vice versa.

Gharib et al. [42] examined the job stress of academic staff working at Dhofar University in Sultanate of Oman and how it impacts on job performance. Using 102 structured questionnaire as the tool for collecting data, the study concluded that workload as the source of stress among academic staff working at Dhofar University in the Sultanate of Oman impact positively on job performance. Whereas the role of conflict among academic staff working at Dhofar University in the Sultanate of Oman effect negatively on job performance.

Dankade et al. [19] analyzed stress among vocational secondary school teachers of North East, Nigeria and how it affects their performance. Using simple ramdom sampling, a total of 160 teachers from 18 vocational secondary schools of North East, Nigeria, were selected as samples. The study showed that 
the majority of teachers working in vocational secondary schools of North East Nigeria faced a thoughtful stress mainly because of work-overload, larger class size, and poor students' motivation and discipline. These difficulties lead to poor performance of teachers working in vocational secondary schools of North East Nigeria. At the end of the study the researchers recommended the need for employing the better qualified staff and providing the more classrooms.

Hamid et al. [43] conducted a study dealing with work-related stress and its prospective influence on work performance of Swaziland teachers. Using 377 valid data, the study found that most of the teachers working at the government school of Swaziland education system experienced work-related stress due to that of unfair promotion and personal growth, job dissatisfaction, job control and job retention. At the end of the study, researchers recommended the need for Swaziland Department of Education to minimize the feeling of stress in order that high performance of teachers working in the Swaziland education system is adequately promoted.

Awadh et al. [44] examined the work-related stress of workers in the County Government of Kilifi, Kenya and its eventual impact on performance. Using a total of 2300 employees as samples, the study found that work-related stress of workers in the County Government of Kilifi impact positively on their performance. The study recommended the need for the County Government of Kilifi to design effort of organizing employees' burnout and of creating a more sufficient time for employees to be with their family.

Ahmed and Ramzan [45] conducted a study examining the effect of work-related stress on the job performance of workers in banking sector of Pakistan. Using a total of 144 workers as the source of data, the study found a negative correlation between work-related stress of workers and their performance. At the end of the study, the researchers suggested a need for management to create conducive climate among the workers in order that high performance of workers would be adequately promoted.

Anandasayanan and Subramaniam [46] conducted a study examining the effect of work-related stress of teachers with special reference to Jaffna district schools and its eventual impact on their performance. Using a total of 150 teachers (28 unmarried and 122 married) as samples, the study found that teachers under stress cannot perform well due to that of the decrease of teachers' motivation and the increase of teachers' absenteeism. Researchers then recommended a need for reducing teacher absenteeism and enhancing teacher motivation.

Dar et al. [47] examined work-related stress of workers in business sector of Pakistan and its eventual impact on their performance. Using structured questionnaire as tool of gaining data from a total of 143 workers, the study found that work-related stress leads to workers' inability to focus, workers' inability to think well, and workers' inability to make decision. The researchers then concluded that work-related stress and performance of workers in the business sector of Pakistan was negatively correlated. The researchers further underlined a need for reducing work-related stress in order that high performance of workers in the business sector of Pakistan would be promoted adequately.

Despite the huge number of accessible literature examining the work-related stress and how it may affect performance (e.g. [10, 20, 39-47]), we feel the need of looking seriously on this topic within the context of Boven Digoel district, Indonesia, to address the local demand of having loyal and dedicated teacher and of having capable primary school graduates [14, 15]. Result of this study might be similar enough to the previous ones, but as this study provides the first empirical study of Indonesian education scheme exploring the eventual correlation between the work-related stress of primary school teachers and their performance within the context of Boven Digoel district, result of this study may hypothetically add the accessible literature by giving a cherished extension of related researches in other countries. This study focused on the endeavor of exploring the work-related stress of teachers working in the primary schools of Boven Digoel district and its eventual correlation with their performance.

\section{RESEARCH METHOD}

As this study pursuit to describe the eventual correlation between the work-related stress of primary school teachers of Boven Digoel district and their teaching performance, a quantitative method using survey study was employed based on the following six advantages: (a) low cost, (b) precise results, (c) high representativeness, (d) appropriate data collecting, (e) useful statistical implication; and (f) minimum researchers' prejudice [48].

Employing incidentally sampling technique, data were collected from a total of 352 primary school teachers. Job performance of teachers in primary schools of Boven Digoel, Papua, was measured using 15 items of questionnaire from a study piloted by Wolomasi et al. [49]. An Indonesian language version of the questionnaire using a four-point Likert's scale, scored from 1 (strongly disagree) to 4 (strongly agree), was distributed to 352 teacher-informants. Sample of the English version of items are follows: "I organize teaching-learning materials in such a way for understanding", the at the beginning of school year",

Int. J. Eval. \& Res. Educ. Vol. 9, No. 2, June 2020: 352 - 358 
"I individually prepare different learning media to teach for understanding", "I persistently assess students work", "I personally provide learning media which are not provided by the school", "I generally set an occasion to partake in education forums or symposiums to overhaul informations and aptitudes", and "I create opportunities for students to manage class-discussion".

The work-related stress of primary school teachers of Boven Digoel district, Indonesia, was measured by modifying a survey questionnaire developed by Kyriacou and Chien [50] into 9 items, scored from 1 (No Stress) to 4 (Extreme Stress). An Indonesian language version of the questionnaire using a four-point Likert's scale, scored from 1 (No Stress $=$ NS) to 4 (Extreme Stress $=$ ES) was distributed to 352 teacher-informants. Sample of the English version of items are follows: "Changeable education curriculum and government policy", "Parents' unawareness on the importance of education", "Poor working conditions", "Management style of the school principal", "Not enough teaching resources", "Students who lack motivation".

Raw data were statistically analyzed using Pearson's correlation analysis technique by employing the Statistical Package for the Social Sciences (SPSS) version 21. One research hypothesis $\left(\mathrm{H}_{\mathrm{a}}\right)$ was suggested to be tested is that the work-related stress and performance of primary school teachers of Boven Digoel district, Indonesia, will be significant negatively correlated.

\section{RESULTS AND DISCUSSION}

This study described the eventual correlation between work-related stress of primary school teachers of Boven Digoel district, Indonesia, and their performance. As aforementioned, the correlation between the two variables was statistically examined using Pearson's correlation analysis. The significant outcome of Pearson's correlation analysis can be seen in Table 1.

Data in Table 1 shows that work-related stress and performance of primary school teachers of Boven Digoel district, Indonesia, are significant negatively correlated. As, at the level of alpha $(\alpha)=.05$, the coefficient value of Pearson Correlation is -.916 and the significant value is .000 then the research hypothesis that work-related stress and performance of primary school teachers of Boven Digoel district, Indonesia, will be significant negatively correlated is accepted, while the null hypothesis $\left(\mathrm{H}_{0}\right)$ is rejected.

As the coefficient value of Pearson's correlation is significant negative means that adding one digit in work-related stress will decrease 0.916 digit in performance of primary school teachers of Boven Digoel district, Indonesia. In reverse, reducing one digit in the work-related stress will add 0.864 digit in the performance of primary school teachers of Boven Digoel district, Indonesia. It inferred that the lower work-related stress of teachers, the higher teachers' performance; the higher work-related stress of teachers, the lower teachers' performance.

Table 1. Work-related stress and performance of primary school teachers of Boven Digoel

\begin{tabular}{cccc}
\hline & & & \\
& & Stress & Job_Performance \\
\hline \multirow{3}{*}{ Stress } & Pearson Correlation & 1 & $-.916^{* *}$ \\
& Sig. (2-tailed) & & .000 \\
& $\mathrm{~N}$ & 352 & 352 \\
Job_Performance & Pearson Correlation & $-.916^{* *}$ & 1 \\
& Sig. (2-tailed) & .000 & \\
**. Correlation is significant at the 0.01 level (2-tailed). &
\end{tabular}

Teachers play a pivotal role in delivering quality education for the youths and, for the quality of education, the quality of teachers matter a lot. Therefore, it is crucial for schools to recruit and to keep highly quality and committed teachers in order to produce good quality of nation's youth. A qualified teacher, in fact, becomes a role model for students and his/her thoughtful attitude will impact greatly on students' life [51]. Teaching is a very challenging profession. In today's world where industrialization and technology become an integrating part of modern community's life, teaching becomes a profession involving many stresses. Not surprisingly if the intensity of teachers' work-related stress, as of late, have expanded globally (McIntyre as cited in [52]). In Indonesian context, apart from the conflicting demands from education administrators and stakeholders, Indonesian teachers must also contend with chronic work overload (teaching minimum 40 hours per week), poor working conditions, and national education curriculum and policies that rapidly shifting. These experiences may evoke teachers' negative emotions which may ultimately result in teachers' burnout, depression, dissatisfaction, poor performance, poor attendance, and then desire to leave the teaching profession [53, 54]. 
Keeping on the view that teachers' work-related stress may affect teachers' capacity to teach the youth of nation, result of this study might be crucial for school leaders to take deliberate effort of helping teachers to cope with their work-related stress. Fair treatment, equitable rewards, and recognition for good work are of, among others, the school principals' paramount effort of fostering morale and job satisfaction among teachers and, in turn, helping teachers to cope with stress. "There is no doubt that teachers themselves prefer principals who are honest, communicative, participatory, collegial informal, supportive and demanding and reasonable in their expectations with a clear vision for the school - principals who work 'with' rather than "through" [55]. In the similar way, Werang [56] argued that teachers are likely to feel more delighted when they work under a thoughtful caring leader.

Researches on teachers' work-related stress revealed that teachers with extreme stress have poorer relationships with students who they perceived as challenging [57], tend to be less tolerant to their students [58], and have more negative emotions toward their students than their colleagues with less stress [59]. Anderson [60] contended that exceptional successful teachers tend to have higher gains in student academic achievement and vice versa. In the similar way, Learning Liftoff [61] asserted that students who are taught by teachers with the highest level of stress tend to have low academic achievement and misbehave.

Comparing to the findings of current relevant studies as it were aforestated, the Pearson's coefficient value of this study is categorized very high $(\mathrm{r}=.916)$. The Pearson's coefficient value of $\mathrm{r}=.916$ means that $91.6 \%$ of the performance of primary school teachers of Boven Digoel district, Indonesia, is predicted by their work-related stress. Despite the similarity of the finding with the previous ones, this finding remains important and significant as it calls for an immediate action from the school leaders to eliminate teachers' work-related stress in order that the performance of primary school teachers of Boven Digoel district, Indonesia, will be promoted adequately. Besides, the result of this study may also hypothetically add the accessible literature on this topic as it provides a first look on Indonesian education scheme exploring the correlation between the work-related stress and performance of primary school teachers within the context of Boven Digoel district, Indonesia.

\section{CONCLUSION}

To summarize, this study pursuit to describe the eventual correlation between the work-related stress and performance of primary school teachers of Boven Digoel district, Indonesia. Grounded on the statistical analysis as it has formerly been deliberated, it can be concluded that the work-related stress and performance of primary school teachers of Boven Digoel district, Indonesia, are significant negatively correlated.

As this study provides the first empirical study on Indonesian school scheme exploring the eventual correlation between the work-related stress and job performance of primary school teachers within the context of Boven Digoel district, result of this study may hypothetically add the accessible literature by giving a cherished extension of related researches in other countries. Finding of this study may be practically crucial for the school leaders to take deliberate effort of generating more pleasurable workplace conditions for teachers to teach the youth of nation. The more teacher enjoy with their lives and work of teaching, the less teachers' stress. The less teacher stress, the more teachers produce the quality work of teaching.

This study is conducted in a very limited coverage area (primary schools of Boven Digoel district) with a very small size of samples (352 teachers only). Hence, finding of this study should be strictly interpreted and generalized for the whole part of Papua and of Indonesia as well. To generalize the result, future studies on this topic with a broader area and a bigger sample will be fully recommended.

\section{REFERENCES}

[1] J. P. R. French, R. D. Caplan, and R. V. Harrison, The mechanism of job stress and strain, Chichester: Wiley, 1982.

[2] M. A. J. Olivier and D. J. L. Venter, "The extend and causes of stress in teachers in the George Region," South African Journal of Education, vol. 23, no. 3, pp. 186-192, 2003.

[3] C. A. Bakare, "The dynamic of psychological stressors and management of human stress," Human Resources Journal, vol. 1, no. 2, pp. 104-112, 2005.

[4] G. J. Boyle, M. G. Borg, J. M. Falzon and A. J. Baglioni, "A structural model of the dimensions of teacher stress," British Journal of Educational Psychology, vol. 65, no. 1, pp. 49-67, 1995.

[5] O. Clipa, "Stress factors and solutions for the phenomenon of burnout of preschool teachers," Procedia-Social and Behavioral Sciences, vol. 80, pp. 916-923, 2015.

[6] O. Clipa, "Teacher stress and coping strategies," in O. Clipa (Ed.), Studies and Current Trends in Science of Education, Suceava, Romania: LUMEN Proceedings, pp. 120-128, 2017.

[7] R. Dick and U. Wagner, "Stress and strain in teaching: A structural equation approach," British Journal of Educational Psychology, vol. 71, no. 2, pp. 243-259, 2001. 
[8] J. Griffith, A. Steptoe, and M. Cropley, "An investigation of coping strategies associated with job stress in teachers," British Journal of Educational Psychology, vol. 69, no. 4, pp. 517-531, 1999.

[9] A. A. Ignat and O. Clipa, "Teachers' satisfaction with life, job satisfaction and their emotional intelligence," Procedia-Social and Behavioral Sciences, vol. 33, pp. 498-502, 2012.

[10] C. Kyriacou, "Teacher stress: directions for future research," Educational Review, vol. 53, no. 1, pp. 27-35, 2001.

[11] C. J. Travers and C. L. Cooper, Teacher under pressure: Stress in the teaching profession. London, UK: Routledge, 1996.

[12] B. R. Werang, "The effect of workload, individual characteristics, and school climate on teachers' emotional exhaustion in elementary schools of Papua," Cakrawala Pendidikan, vol. 37, no. 3, pp. 457-469, 2018.

[13] M. Morgan and K. Kitching, "Teaching in disadvantaged schools: job satisfaction of beginning teachers," in A. L. Gilligan and P. Downes (Eds.), Educational Disadvantage in Ireland, Dublin: Institute of Public Administration, pp. 367-378, 2007.

[14] Werang, B. R., Leba, S. M. R., and Pure, E. A. G., "Factors influencing teacher absenteeism in the remote elementary schools of Indonesia: Empirical proof from southern Papua," International Journal of Management in Education, vol. 11, no. 3, pp. 223-247, 2017.

[15] B. R. Werang, et al, "Increasing teacher attendance in Indonesia: A Longitudinal study in the remote elementary schools of Southern Papua," International Journal of Management in Education, vol. 13, no. 2, pp. 133-155, 2019.

[16] K. S. Wong and W. H. Cheuk, "Job-related stress and social support in kindergarten principals: the case of Macau," International Journal of Education Management, vol, 19, no. 3, pp.183-196, 2005.

[17] D. H. Olson, H. I. McCubbin, H. L. Barners, M. J. Muxen, A. S. Larsen, and M. A., Wilson, Families: What makes them work? California: Sage Publications, 1989.

[18] J. Dunham, Stress in Teaching, 2 ${ }^{\text {nd }}$ Edition. London: Routledge, 1992.

[19] U. Dankade, et al., "Analysis of job stress affecting the performance of secondary schools' vocational technical teachers in North East Nigeria," Journal of Technical Education and Training, vol, 8, no. 1, pp. 43-51, 2016.

[20] C. Kyriacou and J. Sutcliffe, “A model of teacher stress," Educational Studies, vol. 4, no. 1, pp. 1-6, 1978.

[21] National Institute for Occupational Safety and Health, Stress at work, DHHS (NIOSH) Publication No. 99-101, 1999. [Online], Available: http://www.cdc.gov/niosh/stresswk. html. [Accessed on September 8, 2018].

[22] World Health Organization, Raising awareness of stress at work in developing countries: A modern hazard in a traditional working environment, 2007. [Online]. Available: https://www. who.int/...health/publications/ raisingawarenessof [Accessed on August 15, 2018]

[23] M. R. Chen and G. Miller, "Teacher stress: a review of the international literature," Eric Document 410187, pp. 3-22, 1997

[24] M. H. Fisher, "Factors influencing stress, burnout, and retention of secondary teachers," Current Issues in Education, vol. 14, no. 1, pp. 1-36, 2011.

[25] C. Forlin, "Inclusion: Identifying potential stressors for regular class teachers," Educational Research, vol. 43, no. 3, pp. $235-245,2001$.

[26] A. M. Geving, "Identifying the types of student and teacher behaviors associated with teacher stress," Teaching and Teacher Education, vol. 23, no. 5, pp. 624-640, 2007.

[27] W. H. Gmelch, P. K. Wilke and N. P. Lovrich, "Dimension of stress among university faculty: Factor-analytic results from a national study," Research in Higher Education, vol, 24, no. 3, pp. 266-286, 1986.

[28] T. Haydon, M. M. Leko, and D. Stevens, "Teacher stress: Sources, effects, and protective factors," Journal of Special Education Leadership, vol. 31, no. 2, pp. 99-107, 2018

[29] R. Klassen and M. M. Chiu, "Effects on teachers' self-efficacy and job satisfaction: Teacher gender, years of experience, and job stress," Journal of Educational Psychology, vol. 102, no. 3, pp. 741-756, 2010.

[30] C. M. Kokkinos, "Job stressors, personality and burnout in primary school teachers," British Journal of Educational Psychology, vol. 77, no. 1, pp. 229-243, 2007.

[31] Needle, R. H., Griffin, T., Svendsen, R., and Berney, C., "Teacher stress: Causes and consequences," Journal of School Health, vol. 50, no. 2, pp. 96-99, 1980.

[32] J. P. Robinson, "Teacher stress: causes, stages, and effects," Journal of Health Occupations Education, vol. 4, no. 1 , pp. 68-80, 1989.

[33] W. C. Borman and S. J Motowidlo, "Expanding the Criterion domain to include elements of contextual performance," in N. Schmitt and W. C. Borman (Eds.), Personnel Selection in Organizations, San Francisco, CA: Jossey-Bass, pp. 71-98, 1993.

[34] M. E. Bergman, et al, "Test of Motowidlo et al.'s (1997) theory of individual differences in task and contextual performance," Human Performance, vol. 21, pp. 227-258, 2008.

[35] W. C. Borman and S. J. Motowidlo, "Task performance and contextual performance: The meaning for personnel selection research," Human Performance, vol. 10, no. 2, pp. 99-109, 1997.

[36] S. J. Motowidlo, et al., "A theory of individual differences in task and contextual performance," Human Performance, vol. 10, no. 2, pp. 71-83, 1997.

[37] S. J. Motowidlo and M. J. Schmit, "Performance assessment in unique jobs," in D. R. Ilgen and E. D. Pulakos (Eds.), The changing nature of job performance: Implications for staffing, motivation, and development. San Francisco, CA: Jossey-Bass, pp. 56-86, 1999.

[38] S. Sonentag, J. Volmer and A. Spychala, Job performance, 2008. [Online]. Available: https://www. researchgate.net/publication/45523650_Job_performance [Accessed on March 25, 2018]

[39] B. S. Yunarti, et al, "Stress and performance of elementary school teachers of Southern Papua: A Survey Approach," Universal Journal of Educational Research, vol. 8, no. 3, pp. 924-930, 2020. 
[40] M. Vijayan, "Impact of job stress on employees' job performance in Aavin, Coimbatore," Journal of Organisation and Human Behaviour, vol. 6, no. 3, pp. 21-29, 2018.

[41] E. P. Amoako, et al, "The effect of occupational stress on job performance at Aspeta Company Limited," Global Journal of Arts, Humanities and Social Sciences, vol. 5, no. 8, pp. 1-17, 2017.

[42] M. N. Gharib, et al "The impact of job stress on job performance: A case study on academic staff at Dhofar University," International Journal of Economic Research, vol. 13, no. 1, pp. 21-33, 2016.

[43] Z. Hamid, C. Bisschoff, and C. Botha, "Work stress and its influence on the work performance of Swaziland teachers in the Swaziland school education system," Journal of Psychology, vol. 6, no. 2, pp. 142-157, 2015.

[44] I. M. Awadh, L. Gichinga, and A. H. Ahmed, "Effect of workplace stress on employee performance in the county governments in Kenya: A case study of Kilifi County Government," International Journal of Scientific and Research Publication, vol. 5, no. 10, pp. 1-8, 2015.

[45] A. Ahmed and M. Ramzan, "Effect of job stress on employees' job performance: A study on banking sector of Pakistan," IOSR Journal of Business and Management, vol. 11, no. 6, pp. 61-68, 2013.

[46] S. Anandasayanan and V. A. Subramaniam, "Effect of stress on teachers' performance with special reference to Jaffna district schools," Paper Presented in the International Conference Conducted in University of Sairam, 2013. [Online]. Available: https://papers.ssrn.com/sol3/papers.cfm?abstract_id=2386067

[47] L. Dar, A. Akmal, M. A. Naseem, and K. U. D. Khan, "Impact of stress on employees' job performance in business sector of Pakistan," Global Journal of Management and Business Research, vol. 11, no. 6, pp. 1-5, 2011.

[48] D. Wea, B. R. Werang, H. P. Asmaningrum and O. Irianto, "Teachers' working conditions and job performance in the elementary schools of Indonesia: A Survey from Southern Papua," The International Journal of Educational Organization and Leadership, in print.

[49] A. K. Wolomasi, S. I. Asaloei, and B. R. Werang, "Job satisfaction and performance of elementary school teachers," International Journal of Evaluation and Research in Education, vol. 8, no. 4, pp. 575-580, 2019.

[50] C. Kyriacou and P. Y. Chien, "Teacher stress in Taiwanese primary schools," Journal of Educational Enquiry, vol. 5, no. 2, pp. 86-104, 2004.

[51] R. Kumar, The importance of teacher, 2016. [Online]. Available: https://www.saddahaq.com/importance-ofteachers-in-society-and-education [Accessed on March 25, 2018].

[52] G. Felloe, Sources of teacher stress, 2015. [Online]. Available: https://www.teachermagazine.com.au/.../ sourcesof-teacher-s [Accessed on August 15, 2018]

[53] F. Betoret, "Stressors, self-efficacy, coping resources, and burnout among secondary school teachers in Spain," Educational Psychology, vol. 26, no. 4, pp. 519-539, 2006.

[54] E. Jepson and S. Forrest, "Individual contributory factors in teacher stress: the role of achievement striving and occupational commitment," British Journal of Educational Psychology, vol. 76, no. 1, pp. 183-197, 2006.

[55] C. Day, A. Harris, M. Hadfield, H. Tolley, and J. Beresford, Leading Schools in Times of Change. Buckingham: Open University Press, 2000.

[56] B. R. Werang, "A study of relationships in Christian Primary Schools of Boven Digoel Regency, Papua, Indonesia," The International Journal of Educational Organization and Leadership, vol. 22, no. 2, pp. 25-31, 2015.

[57] S. J. Yoon, "Teacher characteristics as predictors of teacher-students' relationships: stress negative effect and self-efficacy," Social Behavior and Personality, vol. 30, no. 5, pp. 485-493, 2002.

[58] C. M. Kokkinos, G. Panayiotou and A. M. Davazoglou, "Correlates of teacher appraisals of students behaviors," Psychology in the Schools, vol. 42, no. 1, pp. 79-89, 2002.

[59] P. A. Jennings and M. T. Greenberg, "The prosocial classroom: Teacher social and emotional competence in relation to child and classroom outcomes," Review of Education Research, vol. 79, no. 1, pp. 491-525, 2009.

[60] L. W. Anderson, Increasing teacher effectiveness. Unesco: International Institute for Educational Planning, 2004.

[61] Learning Liftoff, "Top 3 causes of teacher stress and how it affects students," 2018. [Online]. Available: https://www.learningliftoff.com/how-teacher-stress-affects-students/ 